\title{
NIGHT CALLS IN A B.A.O.R. PRACTICE
}

\author{
Captain P. J. HOYTE, L.R.C.P., M.R.C.S., D.Obst.R.C.O.G., R.A.M.C. \\ 7 Field Ambulance R.A.M.C., B.A.O.R.*
}

SUMMARY: A total of 1075 night calls in a typical general practice in B.A.O.R. are analysed. Forty seven per cent were seen by $8 \mathrm{p} . \mathrm{m}$. in the evening, and 23 per cent after 11 p.m. Respiratory conditions represented the major cause of morbidity (32 per cent). The demand made on the service by children ( 48 per cent) was much higher than their actual proportion in the garrison ( 37 per cent). Twelve per cent of all the patients needed hospital admission.

This survey of general practice night calls in Osnabruck, British Forces Post Office 36, covers the period 1 January to 30 June 1969 (181 days), details being given of all patients treated between 5 p.m. and 8 a.m. the following morning (Saturdays and Sundays are included on the same basis).

\section{General Background}

Osnabruck is an attractive city in North-West Germany. It is a prominent cultural centre, visited by many Germans for meetings and congresses of one sort or another. While there are many places of great historical interest in the city, a large part of it is new, having been rebuilt after the second World War; there is a considerable amount of light industry. The population of the city is approximately 142,000 (roughly comparable with Stockport or Birkenhead).

In terms of temperature, the climate in the region is very similar to that in much of England. Average monthly temperatures are: January $2.4^{\circ} \mathrm{C}\left(36^{\circ} \mathrm{F}\right)$ and June $16.8^{\circ} \mathrm{C}$ $\left(62^{\circ} \mathrm{F}\right)$.

However due to the convergence of the maritime and continental climate patterns in the region, the weather conditions are very changeable, and extremes of temperature are the rule.

At the time of this survey, the British garrison in Osnabruck was approximately 5,000 strong, being made up of a brigade group, with many extra divisional and corps troops. The major units were: 1st Royal Tank Regiment, 1st Bn. Royal Scots. 1st Bn. King's Own Scottish Borders. 1st Bn. Devons and Dorsets. 23 Corps Engineer Regiment and 25 Corps Engineer Regiment.

In addition to the troops, there were approximately 2,160 families in married quarters or hirings in and around the city, including some from other garrisons in B.A.O.R. The total number of children was estimated at just over 4,500. (A random survey of families attending my own medical centre in a week in the middle of JanuaryJune period totalled 210 children per 100 families.)

Attached civilians (consisting mostly of B.F.E.S., S.S.A.F.A., M.P.B.W. and N.A.A.F.I.,) brought the total number of British people to about 12,000 , that is about 8.5 per cent of the total population of Osnabruck.

Almost all the members of the garrision were resident in three main areas of varying size, the extremes being about 10 miles apart.

*Now: Garrison Medical Centre, Ayios Nikolaos, Cyprus, British Forces Post Office 53. 


\section{Medical organization}

Medical cover was provided by the medical officers of 7 Field Ambulance, R.A.M.C. At the time of the survey there were 8 doctors on unit strength, of whom 5 would be engaged on medical duties, the other 3 being on leave, exercise, or in administration.

Night work was organised on a rotational basis. Most of the doctors worked on average 1 night in 5 when available; one doctor worked 1 night in 8 , while another did 5 nights only.

Night calls were handled exclusively by the Medical Reception Station (M.R.S.), situated at one end of the practice area. This was staffed by R.A.M.C. medical orderlies, who could then reach the doctor on duty by telephone. Ambulances were also based at the M.R.S. Patients were either seen there, or visited in their own homes.

Patients requiring hospital admission had either to be retained in the M.R.S. ( 20 beds-adult males only) or sent to the nearest British Military Hospital in Munster, about 35 miles away. For urgent cases, there were excellent German maternity, paediatric, and general hospitals in Osnabruck itself.

\section{Results}

During the survey period, a total of 1075 patients were treated, at an average of 5.9 patients a night. The maximum number treated in any one evening was 13 (three times), and the minimum 1 only (twice). There was no apparent seasonal variation (Fig. 1).

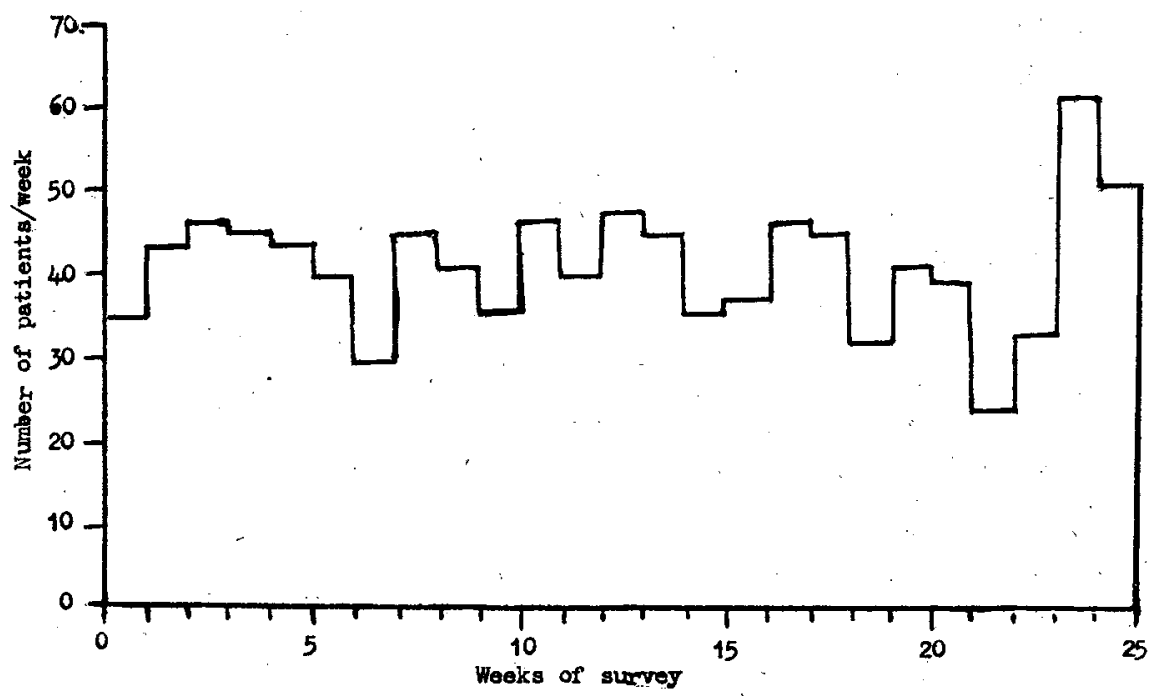

Fig. 1. Incidence of night calls expressed as a weekly total.

In addition there were 58 patients with spontaneous onset of labour, but rightly or wrongly, these were frequently handled by the night orderly on his own initiative; and so have been omitted from the totals.

The split by sexes is shown in Table I, as compared with the approximate garrison 
Table I

Calls split by age and sex

\begin{tabular}{|c|c|c|c|c|}
\hline \multirow{2}{*}{$=$\begin{tabular}{cc}
$a$ \\
\hdashline$a n$
\end{tabular}} & \multirow{2}{*}{$\begin{array}{l}\text { Garrison strength } \\
\text { per cent }\end{array}$} & \multicolumn{3}{|c|}{ Medical calls } \\
\hline & & per cent & & Absolute \\
\hline $\begin{array}{l}\text { Men } \\
\text { Women } \\
\text { Children }(<15)\end{array}$ & $\begin{array}{l}43 \\
20 \\
37\end{array}$ & $\begin{array}{l}30 \cdot 5 \\
21 \cdot 5 \\
48 \cdot 0\end{array}$ & & $\begin{array}{l}327 \\
232 \\
516\end{array}$ \\
\hline
\end{tabular}

Table II

Principal indications for treatment

\begin{tabular}{|c|c|c|c|c|c|}
\hline Diagnosis & & Men & Women & Children & Totals \\
\hline $\begin{array}{l}\text { Respiratory } \\
\text { Trauma } \\
\text { Alimentary } \\
\text { Genito-urinary } \\
\text { E.N.T./eyes/skin } \\
\text { Specific fevers } \\
\text { Psychiatric } \\
\text { Alcoholic consumption } \\
\text { Miscellaneous }\end{array}$ & . & 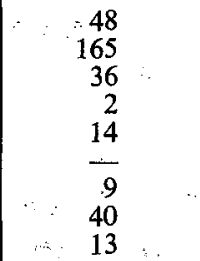 & $\begin{array}{r}40 \\
27 \\
31 \\
74 \\
15 \\
2 \\
27 \\
2 \\
14\end{array}$ & $\begin{array}{r}253 \\
79 \\
\quad 73 \\
5 \\
49 \\
36 \\
\therefore \frac{7}{21}\end{array}$ & $\begin{array}{r}341 \\
271 \\
140 \\
81 \\
78 \\
38 \\
36 \\
42 \\
48\end{array}$ \\
\hline
\end{tabular}

strengths. As one might expect, the children represent a larger percentage of the work load than their actual numerical proportion.

The main indications for treatment were as listed in Table II. The preponderance of traumatic conditions in men, and respiratory conditions in children is very evident. It is also interesting to note that the majority of psychiatric patients seen were women.

Where possible, the májority of patients (900-83 per cent) were seen at the M.R.S. Many of these came there of their own accord, whilst an indefinite number were brought in by ambulance. This had the advantage of allowing the doctor to pay only one visit to the M.R.S. and conduct a small clinic, rather than making a series of separate visits.

Forty-six patients ( 4.3 per cent) with simple complaints were treated by the doctor over the telephone. These were almost all patients seen at the M.R.S. by the night orderly, who did not feel that they justified being seen by the doctor.

The number of patients visited in their own homes was 129 (12 per cent).

There were 128 patients (11.9 per cent) needing hospital admission. Of these, 56 were admitted to the M.R.S. (single soldiers with minor complaints), and 61 patients were sent to the military hospital for admission. Only 11 patients needed urgent admission to local German hospitals, these were for Overdoses 2, Respiratory infections 2, Haematemesis 1, Abortion 1 and Severe trauma 5. (Some patients in labour were also admitted to the German "Frauenklinik").

\section{Times of calls}

Figure 2 shows a time distribution analysis of the calls covered in the survey. Basically speaking the findings are very similar to those demonstrated by Beetor (1969). 


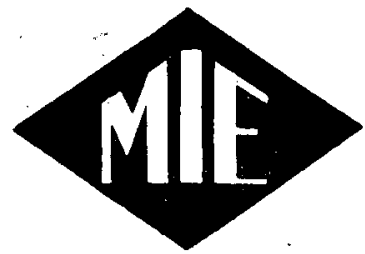

\section{Medical \& Industrial Equipment Limited}

Specialists in :

$\star$ Anaesthetic Apparatus

$\star$ Electronic Monitoring

Equipment

$\star$ Suction Equipment

$\star$ Anaesthetic Sundries

The MIE Cavendish Apparatus is designed as a comprehensive unit to meet every requirement for general inhalation anaesthesia. The Cavendish now incorporates a 60 p.s.i. gas system.

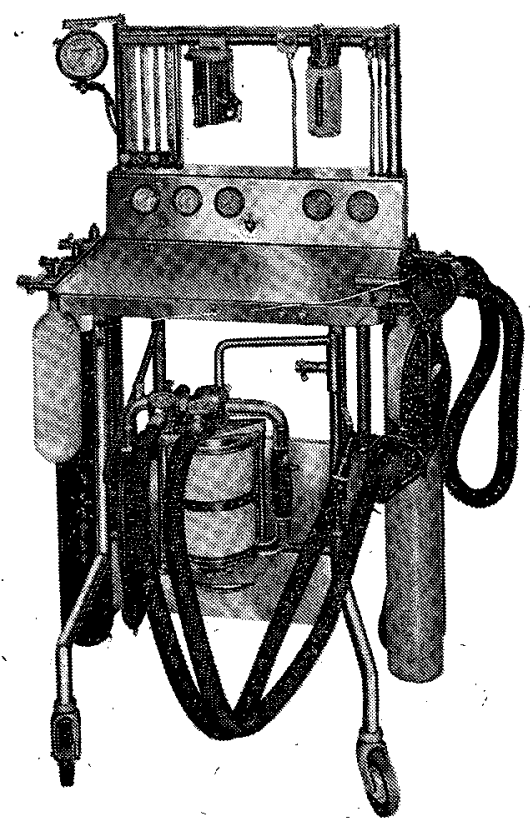

Your enquiries are welcomed

LONDON 26-40 Broadwick Street, London, W1A 2AD

MANCHESTER Tel: 061-224 1481

CANADA Niagara Falls, Ontario

U.S.A. Niagara Falls, N.Y. 


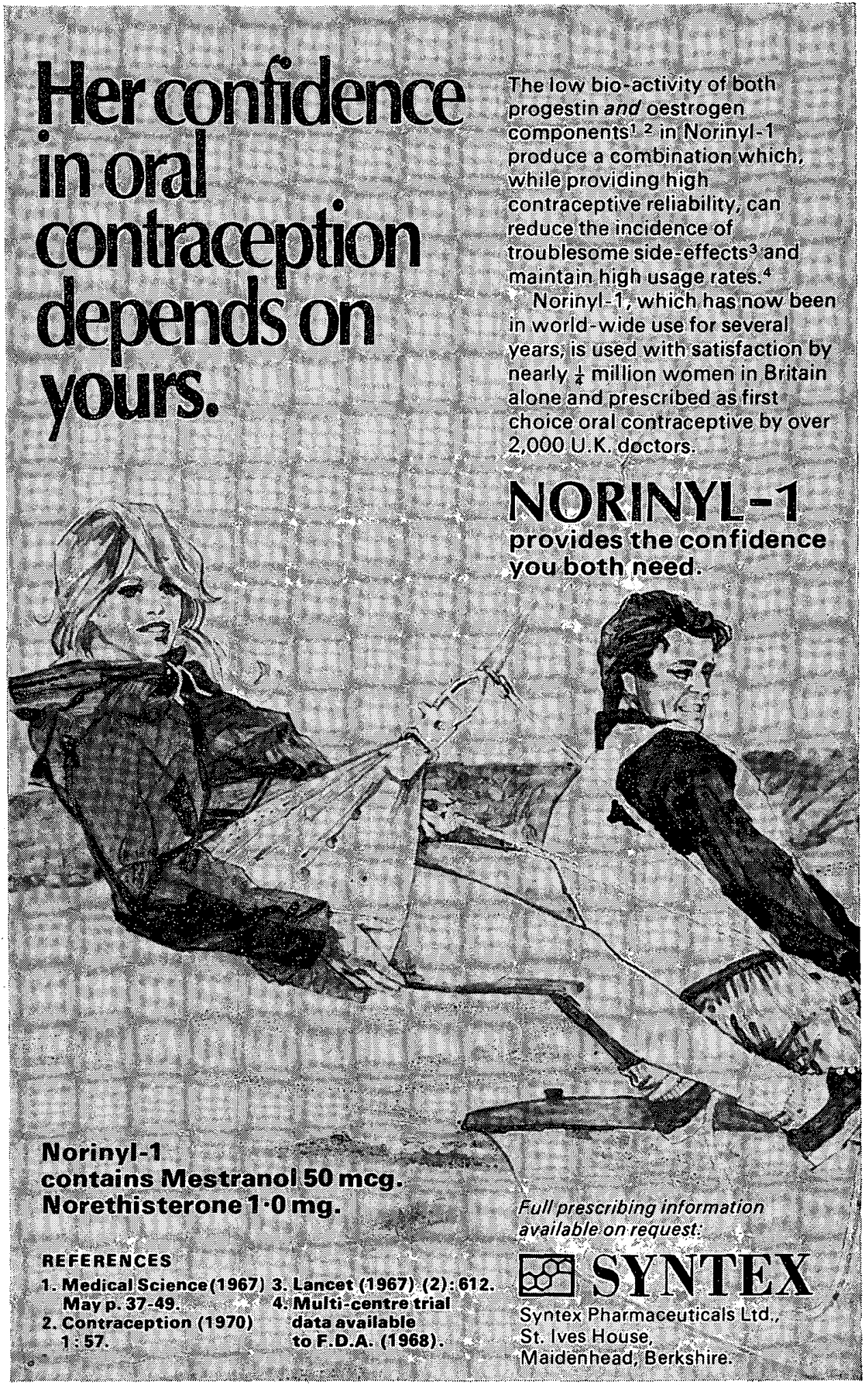




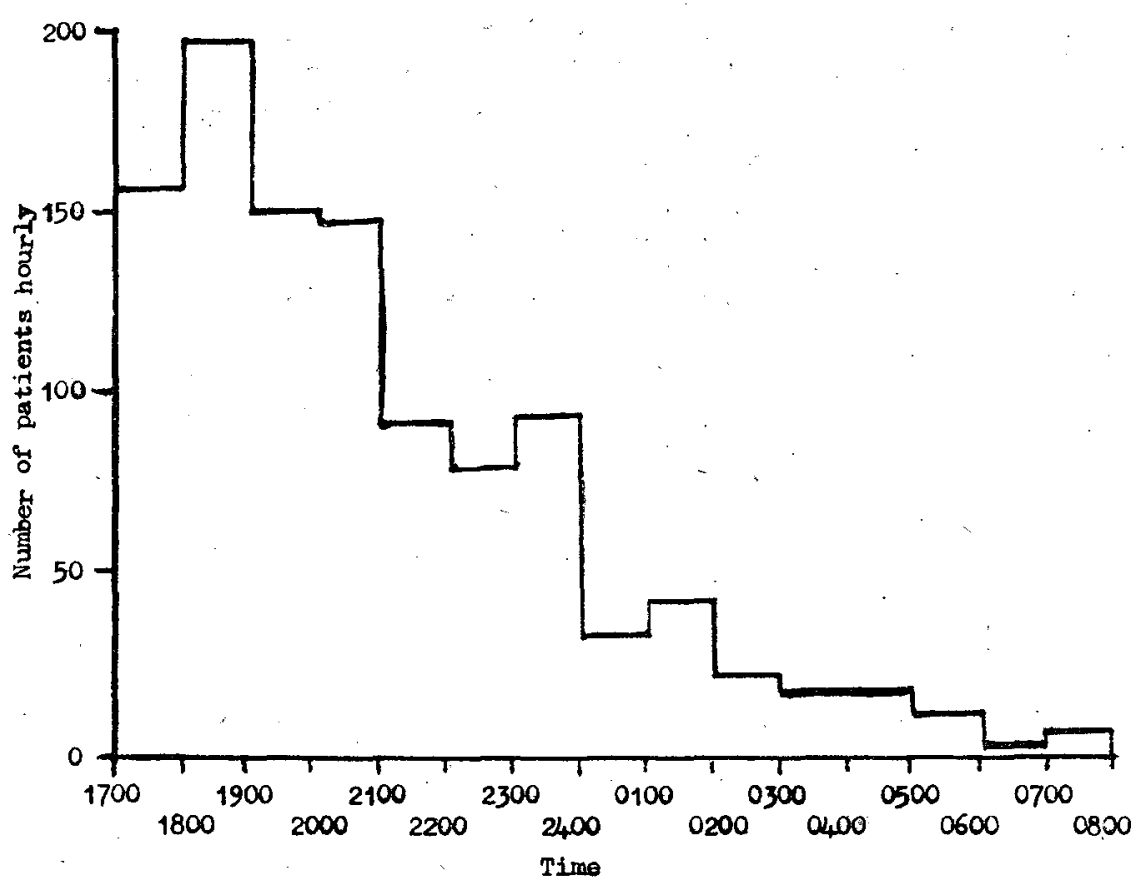

Fig. 2. Hourly distribution of calls.

It may be seen that 355 of the 1075 patients ( 33 per cent) had been treated by 7 p.m., and nearly half (506- 47 per cent) by 8 p.m. One feels that a very high proportion of these calls could have been dealt with during normal working hours.

There were 249 patients ( 23 per cent) treated after 11 p.m. when the doctor might reasonably have been supposed to have gone to bed.

\section{Anomalies}

While no attempt has been made to determine the motives of patients in making seemingly unnecessary calls (Clyne 1961), it is worth recording some of the curious anomalies which arose during the six month period-Insomnia 2, Rubella contact 2, Vaginal discharge 3, Worms 1, Teething. 6, Wind 1, and Constipation 7 cases (one case was recorded by the night orderly as being due to "Constipassion").

\section{Conclusions}

There is considerable abuse of the system; service patients are always said to be " demanding ",; and this is certainly borne out by the numbers seen, especially early in the evening ( 47 per cent by 8 p.m.).

All patients in labour should be seen by the doctor. In many cases patients who could easily have made the trip to the military hospital were sent to the German maternity hospital by the duty orderly.

The doctor should be in direct contact by telephone with the patients. Many trivial calls could have been avoided in this way. 
It is interesting to note how this type of all-embracing general practice splits itself into three main categories, as would be normally experienced in Britain-General Practice 733 cases (68.2 per cent), Casualty Department work 296 cases ( 27.5 per cent), and Police work 46 cases (4.3 per cent).

\section{REFERENCES}

BeEton, D. G. (1969). Practitioner 202, 830.

Clyne, M. B. (1961). Night Calls-a study in General Practice. Tavistock Publications Ltd. London.

\section{Wilkinson Award Scheme 1970}

The following message was received by the Director-General of Army Medical Services from the Adjutant-General, General Sir John Mogg, K.C.B., C.B.E., D.S.O., A.D.C.(Gen.)

"I thought that you would like to know how well we considered 2 Field Hospital and British Military Hospital Dharan did in the 1970 Wilkinson Award scheme. 2 Field Hospital were cited for their good work in Jordan, as part of "Ferrie Force" during 1970, and British Military Hospital Dharan for their achievements in Nepal.

The citations showed clearly that all ranks were unstinting in their efforts to assist the local people. Both units came very high in the gradings to find the best unit for the Wilkinson Award. Their accomplishments reflect great credit on the officers and men of both units and the Army in general.

I have written to congratulate Lieutenant-Colonel Goodhall, Officer Commanding, 2 Field Hospital and Major MacPhie, Officer Commanding, British Military Hospital Dharan, but I thought you too should be aware of the splendid achievements of these two units.

My congratulations." 